\title{
WestVirginiaUniversity
}

THE RESEARCH REPOSITORY @ WVU

Graduate Theses, Dissertations, and Problem Reports

2000

\section{Examining yard sales in Fayetteville, a rural West Virginia town}

Kimberly Dawn Wood

West Virginia University

Follow this and additional works at: https://researchrepository.wvu.edu/etd

\section{Recommended Citation}

Wood, Kimberly Dawn, "Examining yard sales in Fayetteville, a rural West Virginia town" (2000). Graduate Theses, Dissertations, and Problem Reports. 777.

https://researchrepository.wvu.edu/etd/777

This Thesis is protected by copyright and/or related rights. It has been brought to you by the The Research Repository @ WVU with permission from the rights-holder(s). You are free to use this Thesis in any way that is permitted by the copyright and related rights legislation that applies to your use. For other uses you must obtain permission from the rights-holder(s) directly, unless additional rights are indicated by a Creative Commons license in the record and/ or on the work itself. This Thesis has been accepted for inclusion in WVU Graduate Theses, Dissertations, and Problem Reports collection by an authorized administrator of The Research Repository @ WVU. For more information, please contact researchrepository@mail.wvu.edu. 


\title{
Examining Yard Sales in Fayetteville, a Rural West Virginia Town
}

\author{
Kimberly D. Wood
}

A Thesis submitted to the Eberly College of Arts and Sciences at West Virginia University in partial fulfillment of the requirements for the degree of

\author{
Master of Arts \\ In \\ Applied Social Research \\ F. Carson Mencken, PhD., Chair \\ Ronald Althouse, PhD. \\ Joseph Simoni, PhD. \\ Department of Sociology and Anthropology \\ Morgantown, West Virginia \\ 2000
}

Keywords: Informal Economy, Yard Sales, Rural 


\title{
ABSTRACT
}

\section{Examining Yard Sales in Fayetteville, a Rural West Virginia Town}

\author{
Kimberly D. Wood
}

\author{
The informal economy has been a widely \\ studied topic as the economy has changed with a \\ shift from primary to secondary industries. The \\ informal economy is a particular topic of \\ interest in West Virginia, a state with a \\ depressed economy where many citizens participate \\ in informal activities to supplement their \\ income. Yard sales are an understudied informal \\ activity, and one the researcher saw occurring \\ often in rural Fayetteville, West Virginia. A \\ study utilizing in-depth interviews was completed \\ and sought to answer who participated in yard \\ sales, how extensively they participated, and \\ why. It was found that reasons for participation \\ were for social reasons as well as monetary gain, \\ and people were reluctant to deem their \\ involvement as a business activity. Yard sales \\ didn't prove to be the main informal economic \\ activity of Fayetteville, West Virginia, but \\ provided valuable information as to their \\ importance in the realm of informal economic \\ activity
}




\section{ACKNOWLEDGMENTS}

I would like to thank my thesis committee for their time and guidance.

I would like to thank my family and friends for their part in the completion of this thesis. I appreciate all of the support and understanding you provided me while I worked. Your words of encouragement helped me to go on when I didn't feel like it.

I would also like to thank my thesis chair, Dr. Carson Mencken, for his patience, guidance and support. I was at his office door countless times with questions and rough drafts, and he always had the time to help me out. Without your help and guidance, I definitely wouldn't have finished this. Thank you so much.

Finally, I would like to thank the men and women who agreed to participate. Without your help, I could not have completed this research. Thanks for taking the time to help me out. 


\section{TABLE OF CONTENTS}

Abstract-------------------------------------ii

Acknowledgments----------------------------iii

I.) Introduction-----------------------------1

II.) Literature Review-----------------------3

III.) Methods---------------------------------20

IV.) Findings------------------------------34

V.) Discussion and Conclusion---------------68

References Cited----------------------------78

Appendix 1------------------------------------80

Appendix 2------------------------------------85 


\section{CHAPTER 1}

\section{Introduction}

The purpose of this research is to examine who participates in yard sales, how extensively they participate, and what are their reasons for participating in yard sales. To achieve this, the researcher chose a small, rural town to study: Fayetteville, West Virginia. A qualitative approach was thought to be the most effective way to obtain a broad range of information on all aspects of yard saling. The town was divided into areas and the researcher randomized how the areas were chosen. Ten indepth interviews were completed during the course of this research.

This research is important because it adds to the growing body of research on the informal economy. It is difficult to make generalizations about the informal economy, and more research gives us a better understanding of how the informal economy works. Also, this study focuses solely on yard sales. The majority of studies on the informal economy examine a wide range of activities, so as to theorize on the informal economy as a whole. However, it is also important for there to be studies of individual 
activities to analyze how specific activities differ from one another relating to different groups of people participating, different rules, and other aspects that may vary. This study approaches yard sale as an informal economic activity, albeit one with its unique set of rules and players. 


\section{CHAPTER 2}

\section{Literature Review}

\section{West Virginia's shift to a service economy}

The economic restructuring that has occurred in the last generation due to society's shift to

a post-industrial economy has had an adverse effect on West Virginia's economy. In the span of 10 years $(1977$ - 1987), West Virginia lost nearly 70,000 jobs in coal mining and manufacturing (primarily in metals and chemicals) (Maggard 1994). The average salary in coal mining was $\$ 36,400$ per year and in manufacturing the average salary was $\$ 20,000$, while the average salary for the 32,000 service jobs created during this same time frame was $\$ 15,000$ per year (Maggard, 1994). Other average salaries per year for service sector jobs include retail $(\$ 13,000)$, and finance, insurance, and real estate $(\$ 14,500)$ (Center for Economic Research, 1991b).

This transformation has been negative for West Virginia as the population between 1980 and 1990 declined 8\%, median household earnings fell 15\% during the 1980s, and the number of families living in poverty increased 16\%, bringing the state's number of families living in poverty to 25\% (Center for Economic Research, 1991b). The 
loss of primary jobs in coal mining and manufacturing has left West Virginia's already depressed economy in worse shape because the primary

jobs have been replaced with lower-paying, lower-skilled service sector jobs (Maggard, 1994). The shift to a service based economy is also a further disadvantage to West Virginia because the majority of the state is rural and lacks a large metropolitan area. (US Census, 1990). Therefore, some families have been forced to adopt several strategies to survive economically, as many can no longer survive on one income, or on low-paying jobs.

\section{Yard Sales as part of the Informal Economy}

Though families may employ various

strategies, of particular interest is involvement in the informal economy. Various research has been done examining the informal economy and the extent to which households are involved (Jensen et al, 1995; Castells and Portes, 1989; Mencken and Maggard, 1995; Oberhauser, 1992, 1993, 1995; Tickamyer and Wood, 1996). The informal economy is viewed mainly as an addition to total income not as a replacement for formal work. Within the informal economy, yard sales is one activity of 
particular interest that has thus far been understudied.

Yard sales are a very interesting phenomenon and deserve significant attention, as related to their place in the informal economy. Yard sales are often ignored in studies of informal economic activity, though they are common in many places, especially Appalachia (Tickamyer and Wood, 1996) The perception may be that a yard sale is an activity that you take on occasionally rid yourself of old things or items that are no longer of use to you. Often, this may be true. However, based upon personal experience, I have known some people who hold yard sales periodically in an effort to make extra money. Also, I see several yard sales throughout the summer in Fayetteville. Due to these reasons, I felt yard sales required special attention as an informal economic activity and should be studied. I decided to study them exclusively to gain insight into whether or not they are a legitimate informal economic activity. I maintain that my hometown, Fayetteville, West Virginia, would be a sound field site to explore yard sales and discover who participates in yard sales, how extensive is their involvement, and what are their reasons for 
participation. Fayetteville is an adequate site because it is representative of many West Virginia towns; it is small, rural, and depends upon the service sector for the majority of its capital, as well as many jobs.

\section{Previous Research on the Informal Economy}

Defining the informal economy and which activities to include has been difficult and a source of debate among social scientists (Jensen et al., 1995). It is difficult to define the informal economy for various reasons. One issue is the legality of some of these activities. Researchers don't typically include overtly illegal activities, however, many people that participate in the informal economy don't report the income they receive for tax purposes or for fear of losing state benefits, such as SSI or TANF, that they may receive. Another issue involves what activities to include. Different geographical areas may have various activities that would be more practical to engage in. For instance, those in rural areas are more likely to involve themselves in activities that may require land or agricultural equipment (Oberhauser, 1992, 1993, 1995). The way in which researchers conceptualize the informal economy is important, because the definition will affect the results of 
the study as far as participation rates and activities engaged in. For example, researchers are careful not to include activities that people participate in mainly as a hobby (Oberhauser, 1992, 1993, 1995; Jensen et al, 1995; Tickamyer and Wood, 1996).

Also, if a researcher's conceptualization of informal activity includes activities done to "save money", it is likely that the participation rates reported by respondent's will increase. Families may do things such as mow their own lawn to save money and not necessarily because they need to save money, or they may grow a garden because they enjoy the fresh vegetables. In their 1994 and 1995 study of informal economic activity in Kentucky, Tickamyer and Wood eventually excluded "saving money" from their analysis which caused the participation rates to drop (1996). The researchers concluded that "saving money" was not necessarily meaningful when defining informal economy activity (Tickamyer and Wood, 1996). In their Fall 1994 version, when "saving money" was dropped from the analysis, participation reported went from 75\% to slightly over 1/3 (Tickamyer and Wood, 1996). The researchers dropped it because of concerns over its reliability since it was so normative 
(Tickamyer and Wood, 1996). Possibly because of these concerns, Jensen et al. in their study of the informal economy in nonmetro Pennsylvania felt that it was unnecessary to include activities done to save money in their analysis (1995). Jensen et al. define the informal economy as "work activities other than regular formal employment that are remunerated either in cash or in kind" (Jensen et al., 1995). Oberhauser also reports in her qualitative studies involving women's homework in Appalachia that these activities are marketed for monetary gain and barter exchange (Oberhauser, 1992, 1993, 1995). Another way of conceptualizing the informal economy came from Castells and Portes who state that the informal economy "is unregulated by the institutions of society, in a legal and social environment in which similar activities are regulated" (Castells and Portes, 1989). All of these definitions have some similarities, though there differences may contribute to differences in their studies (Mencken and Maggard, 1999).

With their conceptualization of the informal economy in place, the researchers have to conclude what activities they think people will report participating in for cash or in-kind 
benefits. In rural areas, often informal economic activity will require some sort of machinery or land (Jensen et al, 1995). In both rural and urban areas, social and human capital may be required to perform some activities, which people of the lowest incomes might not have (Oberhauser, 1995). Various studies have reported different activities as being the most popular, and these studies also have differences in the activities that they inquire about.

\section{Mencken and Maggard's research}

In Mencken and Maggard's 1994 study of noninstitutionalized West Virginia adults in households with telephones, they reported that nearly $22 \%$ of the households they interviewed engaged in some form of informal economic activity for income or exchange. (1995). Their study is representative of the West Virginia population. The activities in their analysis that were reported with the most frequency were handiwork/home repair (9.7\%), personal services (8.3) \%, and crafts and sewing (6.4\%) (1995). Mencken and Maggard also concluded that not a large portion of total household income is gained through informal economic activity (1995). Twenty six percent of those reporting some form of informal economic activity thought that $10 \%$ or 
more of their income came from informal activities, and only 8\% of those reporting informal economic activity thought that $20 \%$ or more was earned through their informal activities (1995). Also, 80\% of those who engaged in informal activity reported that their primary income earner worked full time the week prior to the interview (1995). These results illustrate that those families who do engage in the informal economy do so mainly as a supplement rather than as a substitute for formal economic activities. Mencken and Maggard also found that it was not the lowest income households, but the near poor and the medium households were the ones most commonly participating in the informal economy (1999). The researchers found that of those households participating, only 5.8\% of low income households were participating (less than $\$ 10,000$ per year), while $34.3 \%$ of both low/medium income households $(\$ 10,000$ to $\$ 20,000)$ and medium income households $(\$ 20,000$ to 40,000$)$ were participating in the informal economy.

\section{Tickamyer and Wood's research}

Tickamyer and Wood (1996) studied the population of Kentucky using the same method, a randomized statewide telephone survey, though they included 3 portions and switched between 
open-ended and close-ended questions to compare the difference between the two methods. The first installment of the study included closedended questions with a list of informal economic activities that they asked the respondents if they participated in (1996). When the researchers listed activities and asked respondents to respond if they or anyone in their house participated in these activities, the most popular were yard sales (16\%), personal service (5.5\%), and yard work (4.5\%) (1996). Tickamyer and Wood also found that nearly three-fourths of Kentucky households reported engaging in some form of informal activity in their Fall 1994 portion of the study, though this included activities done "to save money", which was eventually dropped from their analysis (1996). In subsequent studies, the reported rates of informal economic activity dropped drastically (19\%) and can be partially attributed to study construction (1996). Tickamyer and Wood employed slightly different methods in the three installments of their study, though "core" questions were used in each portion of the study (1996). In the Fall 1994 administration, closed-ended questions were asked regarding 17 activities and whether respondents or anyone in 
their household participated in those activities "to save money, earn extra money or in exchange for something else?" (Tickamyer and Wood, 1996). The phrase "to save money" was eventually dropped from the analysis and the respondent's were explicitly asked not to include activities done for recreation or as a hobby (1996). In the Spring 1995 and Fall 1995 applications of the study were changed for each analysis to observe if the prompts influenced the activities that the respondents reported (1996). The different formats were utilized to examine how the results might be affected depending upon the format used (1996) •

\section{Jensen et al's research}

In their study of informal economic activity among nonmetro Pennsylvania families, Jensen et al. (1995) found the most commonly engaged in activities were personal services (29.7\%), sale of miscellaneous goods (29\%) and the sale of crafts (14.4\%). Jensen et al. achieved a higher rate of reporting than Mencken and Maggard, and Tickamyer and Wood, however, their population had an overrepresentation of poor families, which could account for the higher rates of reporting that Jensen et al achieved (1995). Also, Jensen et al used different techniques than those 
employed by Mencken and Maggard, and Tickamyer and Wood, which may explain the difference (1995) •

To obtain an overrepresentation of low income families, random and nonrandom techniques were used (1995). A cluster design was used so that geographical areas with high poverty rates could be oversampled for the survey, but the researchers were also able to use random techniques to capture the attitudes and experiences of rural families who were not poor (Jensen et al, 1995). Snowball sampling was also used by asking the participants if they knew of anyone who was low income "around here" that they could contact for interviews (1995). In addition, advertisements for the study were put in the local welfare offices (1995). Jensen et al utilized local women to conduct the face to face interviews, because they would be more likely to quickly build a rapport with the respondents (1995) •

\section{Oberhauser's research on women's homework}

Similarly, Ann Oberhauser has conducted various qualitative studies devoted to women's homework and has reported that the most common activities for women are those that represent traditional female skills, such as hair styling, 
cleaning and child care (1992, 1993, 1995).

Oberhauser cites several reasons why more and more women are participating in homework. First, there are a growing number of female-headed households, which puts the economic burden of the family on the woman (1993). Conversely, if the male primary breadwinner is unemployed, the woman of the house may have to get a job to ensure the economic survival of the family (1993). Also, the job opportunities for women are growing, however they are typically within the service sector, which are generally low-paid jobs with little, if any, benefits (Kuhn and Bluestone, 1987). Social services are also being cut, which adversely affects women, specifically women that are the heads of household. To cope with the increasing economic burdens, many women are turning to informal activities, as the formal ones are lacking in stability and may affect any benefits from the state that the women may receive (1993).

Oberhauser's studies were qualitative, which would be conducive to having a flexible interview schedule as far as differing interviews among respondents depending on where the respondent leads the interview (1993). Oberhauser has no mention of yard sales within 
her research, however, her research does focus on traditional female skills (1993). Mencken and Maggard, and Jensen et al did not inquire about yard sales in their respective studies. However, yard sales seem to be an important part of the informal economy as illustrated by the first installment of the Tickamyer and Wood study. Oberhauser also finds that social capital is important in the informal economy. She found that social networks in the production and marketing of goods such as sewing quilts, or the making and selling of crafts are important to the economic success of informal homework activities (1995). Some skills and even social networks can be passed down from one generation to the next, which can help provide the social capital to participate in the informal economy, especially in a small communities when who you know is very important socially (1995). Women of lower socioeconomic status may not have the social networks, skills or other things needed for informal economic activity, such as transportation, which can be a significant problem in a rural state like West Virginia (1995). Also, due to West Virginia's ruralness, many women have to travel to areas outside of their immediate living area to areas where they 
may not know anyone, which requires social skills (1995) .

\section{Purpose of the Research}

Yard sales are an activity that are consistent with the way in which the majority of participants use the informal economy. For the most part, the informal economy is used as a supplement to economic survival, not as the main income. By participating in yard sales, one can earn extra money, while remaining at their home. Remaining at home is an important plus for some women. This would alleviate the need for child care and would also not take away from a woman's domestic duties, which is a legitimate concern for many women, specifically low income women. The problem with the other studiesis that in several questions were not asked about yard sales, and among the studies that were, few questions were asked and they did not provide much detail. To study yard sales, I maintain that a qualitative approach is needed until there is a larger body of research, from which generalizations can be made.

The purpose of my research was to study who participates in yard sales, how extensively and why. These are very generalized questions, however I also maintained some expectations based 
on previous research. I expected that the participants would have to have access to resources such as land (Jensen et al, 1995), as well as social and human capital with which to obtain some of their resources, such as the items they sale (Oberhauser, 1992, 1993, 1995). I also expected that there would be a large majority of women in my study, with this assumption based on Oberhauser's body of research (1992, 1993, 1995). I did not expect to find that a majority of the household's income would be made through yard sales. I believed that yard sales would be a supplement to other, formal income rather than a substitute (Mencken and Maggard, 1999). I felt that most of my respondents would be casual participants, and those that did participate more extensively would be of lower socioeconomic classes (Mencken and Maggard, 1999). Due to the expectations of lower income participants, I expected that the majority of respondents would be high school graduates, and that some would not have finished high school. This would alleviate the need for child care and would also not take away from a woman's domestic duties, which is a legitimate concern for many women, specifically low income women. The problem with the other research is that in several of the studies 
questions were not asked about yard sales. Among the studies that did ask questions regarding yard sales, they failed to provide much detail. To study yard sales, I maintain that a qualitative approach is needed until there is a larger body of research, from which generalizations can be made to design better quantitative instruments. The purpose of my research is to study who participates in yard sales, how extensively and why. These are very generalized questions, however I also maintained some expectations based on previous research. I expected that the participants would have to have access to resources such as land (Jensen et al, 1995), as well as social and human capital with which to obtain some of their resources, such as the items they sale (Oberhauser, 1992, 1993, 1995). I also expected that there would be a large majority of women in my study, with this assumption based on Oberhauser's body of research (1992, 1993, 1995). I did not expect to find that a majority of the household's income would be made through yard sales. I believed that yard sales would be a supplement to other, formal income rather than a substitute (Mencken and Maggard, 1999). I felt that most of my respondents would be casual participants, and those that did participate more 
extensively would be of lower socioeconomic

classes, but not the lowest social class, and I

expected that some of those may receive SSI or

TANF (Mencken and Maggard, 1999). Due to the

expectations of lower income participants, I

expected that the majority of respondents would

be high school graduates, and that some would not

have finished high school. 


\section{CHAPTER 3}

\section{Methods}

\section{The setting}

Fayetteville is a small, rural town located in Fayette County, West Virginia that has a rich history. Abraham Vandal was the founder and first resident, as he purchased the land that is now Fayetteville in 1812. Vandal's home was located in what is now the center of town. Sometime before 1830, Vandal opened a tavern in Fayetteville where travelers could stop for the night. Vandal's tavern functioned as Fayetteville's first business. Originally, Fayetteville was called Vandalia to honor the town's founder and was called such until 1837 when the name was changed to Fayetteville, though the town wasn't incorporated until 1883. Fayetteville took a variation of the county name possibly because of its status as county seat. The county is named for the French nobleman LaFayette, who helped the struggling colonists during the days of the Revolution.

Fayetteville was incorporated in 1883, and at the time of incorporation the population was 125. The first mayor of Fayetteville was W. A. Wiseman, who still has descendants residing in Fayetteville today. The government has remained 
a mayor - city council model since the election of the first mayor. The town itself has remained a residential community throughout its history. The era of industrialization had a positive effect for Fayetteville, as is did for much of the United States. Many of the most beautiful homes today were built during the boom of industrialization, though several have been lost to neglect and expansion. There have also been several pre-planned housing areas, including Lee Addition and Huse Addition. During the Industrial Revolution, many of the men and women of Fayetteville were employed directly or indirectly by the coal mining industry. There were mines in Fayette County and the surrounding counties as well, though there wasn't a mine in Fayetteville. During the height of the coal industry, jobs were plentiful, the wages were high and the union was strong. The types of businesses Fayetteville has seen have widely varied, though some of the most successful through the years have been newspapers, law and banking. Town services have also progressed steadily through the years. In 1901, the first electric power plant was built and a town lighting system was implemented, replacing the gas lights that were previously 
used. In 1910, the wooden sidewalks were replaced with concrete ones, though the streets were not paved until the 1920s, when streets were paved from the center of town out. Sewer lines were put in as the streets were paved. In 1929, the Fayetteville Water Company was started and in 1946, the Sanitation Board was formed.

Fire fighting basically started with a push cart until the volunteer fire department was formed in 1926. The fire fighters first used a 1-ton Ford truck for fire protection. Today the fire department is very modern, has several trucks and is still a volunteer fire department. Cemeteries were a private concern up until 1946. when a Cemetery Board was instituted. Huse Memorial Park was donated to the town at this time, replacing the cemetery on High street as the cemetery primarily used and still functions as such today.

The school system has also seen several, progressive changes throughout the years. The first public school was held in a blacksmith shop for 1 year, then moved to a one-room log building. The school system progressed until Fayetteville contained and still utilizes a fully functioning elementary $(\mathrm{K}-5 \mathrm{th})$, middle (6th 8th), and high school (9th - 12th). 
Though Fayetteville remains a residential community, much of Fayetteville's revenue today is related directly or indirectly to the whitewater rafting industry, which is a secondary or service industry. The industry began in 1968, and at the time the industry was small, employed few and didn't contribute a large percentage of Fayetteville's revenue. The industry remained small until the late $1980 \mathrm{~s}$ when it began to grow rapidly. Today, the industry is a multi-million dollar industry that caters to over a million people per year and employs thousands of people. Fayetteville, also known as the "Gateway to the New River Gorge", is a town teeming with tourism opportunities. The New River Gorge is the second oldest river in the world, behind the Nile. The river and the surrounding area provide a lot of outdoor recreation that attracts tourists. Activities such as rock climbing, mountain biking, kayaking, camping and fishing are just some of the activities that tourists come to Fayetteville to experience. The New River is the leading reason that tourists come to Fayetteville, however. The whitewater industry keeps getting bigger every year. The industry that started small in 1968 achieved heritage tourism status as it marked its 30 th year in 
1998 .

In addition to the New River, the Gauley River is another river that is rafted in Fayette County. However, there are no rafting companies located in Gauley Bridge. The vast majority of rafting companies are located in Fayetteville or just outside its borders, so the local businesses of Fayetteville reap the benefits of having over a million visitors per year. Due to the large number of people that come into Fayetteville to participate in whitewater rafting or other outdoor recreation, there are many unique businesses in the area. For example, there are no less than 15 food establishments, which is a disproportionate amount for such a small town and a few of these businesses are open only from February or March through October to coincide with rafting season. There are businesses that provide antiques, rock climbing equipment, mountain biking trips and equipment, outdoor and camping equipment, organic and healthy food, all of which are unique for a small town. There are also several campgrounds, some of which are owned by rafting companies, bed and breakfast establishments, catering services, a miniature golf course, a go-cart track, two hotels and several convenience stores. There is also a 
business that sends photographers down the New River with the commercial trips to take pictures of the rafters going though the rapids that they may later purchase. There is also a theater that offers several plays throughout the year. These are just a few examples of the types of services that Fayetteville offers.

The majority of the businesses mentioned above are a result of the rafting industry. Though most rafting companies have their own campgrounds and also take pictures and videos of the rafters trip to sell to them, other businesses, called multiplier businesses, also flourish that provide these same services. Much of Fayetteville's economy is related directly or indirectly to the rafting industry.

The whitewater rafting industry employs significant numbers of residents from Fayetteville and the surrounding areas. Some people do migrate into Fayetteville every year for rafting season, and more migrate in as the industry keeps getting bigger. Some of the people that previously migrated into Fayetteville have taken up residence year round. Some of the jobs in the rafting industry pay well, but the majorities of the jobs are relatively low paying, which is typical for service sector jobs. 
Also, most of these jobs are seasonal. A lot of these jobs are occupied by women, typically the office jobs, the rafting company store jobs, the restaurants and catering jobs, though women do hold other positions in the companies, some of which are positions with significant power. The majority of the rafting guides are men, though more and more women are holding this job. This job is higher paid and often guides receive tips from the people on their trips. This job also requires skill and training. Though the jobs are seasonal, they do provide opportunities that these people may not have otherwise, particularly the locals.

Fayetteville rafting season culminates in West Virginia's largest one-day festival on Bridge Day, which is on the third Saturday of October, and is also the last day of Gauley Season. Bridge Day has also grown over the years from the first one over 20 years ago. Bridge Day has over 200,000 visitors every year and offers a wide variety of activities. This is the only day pedestrians can walk on the bridge and traffic is reduced to one lane each for north and southbound traffic. There are a wide variety of vendors who sell crafts, food and clothing to name a few; there is also various entertainment offered. The 
view at this time is spectacular as the fall foliage is typically at its peak. Another exciting activity is the BASE jumpers who are allowed to parachute the 876 feet to the New River on this day. Some years bring special events, such as the time a man bungee jumped off the bridge to achieve the world record, and once a couple, who were also BASE jumpers got married and then jumped off the bridge together.

Fayetteville relies very much on its tourism industry for economic survival. Fayetteville would not have the variety of businesses and services that it does were it not for the whitewater rafting industry.

Due to the seasonal and low paying nature of work in Fayetteville, some families may require income from other sources, such as state benefits or participation in the informal economy. I argue concentration on one understudied activity, yard sales, is a good choice because during the summer months I often see yard sales taking place in Fayetteville. For all of these reasons, I argue that Fayetteville was a sound choice regarding conducting a study on yard sales to discover who participates in yard sales, how extensively and the reasons behind the participation. 


\section{Sampling Yard Sales}

I received IRB approval for my study in early May, roughly 1 to 2 weeks before I began my research. It only took one week for the IRB to approve my research. The reason it was approved so quickly is due to my suggestion that I would not interview anyone that I knew personally. I thought that this may be somewhat of a problem, since I know many people in Fayetteville, however, it never really became an issue. There were two occasions when I passed houses that were having yard sales in the area I had chosen for that day because I knew the people that lived there. It turned out that there were enough people having yard sales that I didn't know that I was able to complete 10 interviews with respondents I did not personally know.

After I had chosen my setting and been approved to complete the research, I needed to develop a way to study the area's yard sales randomly. I obtained a tax map of Fayette county that had the sections of the county gridded off and numbered. Each inch represented 10,000 feet. I marked off the sections of Fayetteville and the outlying areas that though not within the town's city limits are still very much considered a part of Fayetteville. The block of areas I chose were 
$48,49,59,60,61,69,70,71$. Area 50 was not used because it is the beginnings of another community, and while Area 61 is part of Fayetteville it is predominantly wooded area and contains only a handful of areas, which is why the block of areas is of asymmetrical shape. This block best represented Fayetteville and its residents.

To randomize the areas I chose, the areas were picked without replacement. The days of the week weren't randomized, though an effort was made to travel to the areas on different days of the week with the exception of Sunday when yard sales are illegal in Fayetteville. The study began on May 15th and continued until August 15th. During this time, 10 in-depth interviews were completed with 9 of those being tape recorded. One respondent refused to let the interview be tape recorded, and this will be elaborated upon later.

Randomizing the routes by which the areas were approached was not practical because some of the areas had numerous routes by which to enter while others only had one. Different routes were taken to those areas with more than one accessible entry 


\section{Gaining Access}

Once an area was entered into, the first house where a yard sale was taking place or the first signs

that I saw leading to a yard sale were used. After a yard sale was located, an assessment was required before proceeding. Always carrying with me a cover letter and identification, I would enter the yard and begin to browse around. If the yard sale was not crowded, I would chat with the person or persons whom I felt were "in charge of" the yard sale. I would make friendly conversation concerning the weather, items at the sale and various other typical topics two strangers might discuss. Often, I would inquire about the price of items as many people didn't mark the items. If the yard sale was crowded, or had more than 5 or 6 people there, I would simply look around until the crowd thinned out and I could carry on a virtually uninterrupted conversation with the owner.

Eventually, I would choose an item or two to buy. I felt that buying something at the sale was important considering I was momentarily going to be requesting an interview. I bought at least one item at every yard sale. If I had not already mentioned it, I would mention my interest 
in yard sales. At this point, I would give the potential respondent a copy of my cover letter, which explained that I was a graduate student conducting thesis research and that I was interested in studying yard sales, specifically who participates, how extensively, and why. The cover letter also explained that I was interested in interviewing them regarding my study and that the interview would remain confidential and all materials associated with the interview would be destroyed upon completion of the thesis. I would also relate to the potential respondent that I had been a resident of Fayetteville all of my life. I felt this was important to mention because Fayetteville is a small town and association is very important.

By being a resident of Fayetteville, I would automatically achieve more trust than an "outsider" would. This strategy did work in my favor and often the potential respondent would inquire whom my parents or grandparents were. Some of the respondents were aware of who some members of my family were, and while I did not know the respondents personally, being acquainted with specific members of my family did work to my favor. 
After the potential respondent agreed to an interview, I would set up a day and time to come back for the interview, explaining that I did not want to disturb them while they were conducting their yard sale. I always tried to schedule the interview in a day or two, so that too much time would not pass before I saw them again, as they might not remember when the interview was scheduled for, or the rapport might be lost. Accommodating the respondent was my main concern, however and typically I would suggest a day and time, and if this time was inconvenient for the respondent, I would then let them choose a day and time. This system was successful and there was rarely a problem with scheduling interviews within a few days of the initial contact. The respondents were divided into two groups upon completion of their interviews. The respondents were divided into groups with the contingent factor being if their involvement with yard sales was casual or intensive. Respondents who averaged 1 or less yard sales per year were considered to be casual participants, while those that hosted yard sales 2 or more times per year were labeled as intensive participants. The respondents were divided this way to examine if there were any significant differences between 
the two groups, as well as to compare their similarities. 


\section{CHAPTER 4}

\section{Findings}

Ten people were interviewed for this study, 8 women and 2 men. Nine of the respondents were residents of Fayetteville, while one respondent was from the neighboring town of Oak Hill. However, this female respondent was participating in a yard sale located in Fayetteville, so she was eligible to be interviewed. The respondents represented nearly every grid that was selected for the study. Grid 59 was the only grid not represented in this study. This area is less populated than several other grids due to its location beside an interstate and a wooded area that covers part of this area. It is possible that there were one or more yard sales in this area on days that I was looking at other areas. The ages of the respondents ranged from 2375, with an average age of 51. All of the respondents were Caucasian. I agreed not to interview anyone with whom I had a personal relationship. Two times I had to pass a house by because I knew the residents of the home. However, 14 times I went to houses of people I did not know to obtain interviews. There were 4 women who originally agreed to interviews and later decided not to be interviewed. This issue 
is addressed later.

In my study, respondents that had an average of one or less yard sales per year were coded as being casual participants regarding their yard sales. Those respondents who had 2 or more per year were considered to be involved in the yard sales, though some respondents were marginally involved and others were more intensively involved. Sixty percent of the respondents were casual participants in holding yard sales, while $40 \%$ were more intensive about their participation. (See Table 1). 
TABLE 1

RESPONDENTS INVOLVEMENT IN YARD SALES

\begin{tabular}{|c|c|}
\hline $\begin{array}{l}\text { Respondent \# } \\
(\text { avg) }\end{array}$ & Yard sales per year \\
\hline $\begin{array}{c}1 \\
(\text { casual) }\end{array}$ & 1 \\
\hline $\begin{array}{c}2 \\
\text { (intensive) }\end{array}$ & 2 \\
\hline $\begin{array}{c}3 \\
(\text { casual) }\end{array}$ & 1 \\
\hline $\begin{array}{c}4 \\
\text { (intensive) }\end{array}$ & 3 \\
\hline $\begin{array}{c}5 \\
\text { (intensive) }\end{array}$ & $6-8$ \\
\hline $\begin{array}{c}6 \\
\text { (casual) }\end{array}$ & 1 \\
\hline $\begin{array}{c}7 \\
(\text { casual) }\end{array}$ & $.5-1$ \\
\hline $\begin{array}{c}8 \\
\text { (casual) }\end{array}$ & $.5-1$ \\
\hline $\begin{array}{c}9 \\
\text { (intensive) }\end{array}$ & 5 \\
\hline $\begin{array}{c}10 \\
(\text { casual) }\end{array}$ & 1 \\
\hline
\end{tabular}

The level of education of the respondents was slightly higher than expected. There were still more high school graduates (4) than any other category, which was expected. There were also 3 Bachelor's 
degrees, and 1 Masters degree, while 2 of the respondents did not finish high school (see Table 2).

TABLE 2

EDUCATIONAL LEVEL/LAST GRADE COMPLETED

\begin{tabular}{|c|c|}
\hline & $\mathrm{N}$ \\
\hline 9TH GRADE HS & 1 \\
\hline 10TH GRADE & 1 \\
\hline $11 \mathrm{TH}$ GRADE & 0 \\
\hline HS GRADUATE & 4 \\
\hline BACHELORS & 3 \\
\hline MASTERS & 1 \\
\hline
\end{tabular}

The respondents had very different job situations. Not including yard sales, there were 3 respondents who worked in the informal economy, 2 who had jobs in the formal sector, 3 housewives, 2 retired persons and 1 respondent who did not work at all, because she was in school completing her masters degree. This means that only 2 respondents had jobs in the formal sector at the time of the interview (See Table 2.) In my study, many participants in yard sales do not work in the formal economy, though other members of the household do. 
TABLE 3

JOB SITUATION AT TIME OF INTERVIEW

$\begin{array}{rr}\text { FORMAL SECTOR } & \text { Respondent \# } 8 \\ \text { MINISTER } & \text { Respondent \# } 3 \\ \text { EMP LOYED BY COUNTY } & \text { Respondent \# } 6 \\ ----- & \text { Respondent \# } 1 \\ \text { INFORMAL SECTOR } & \text { Respondent \# } 9\end{array}$

RETIRED

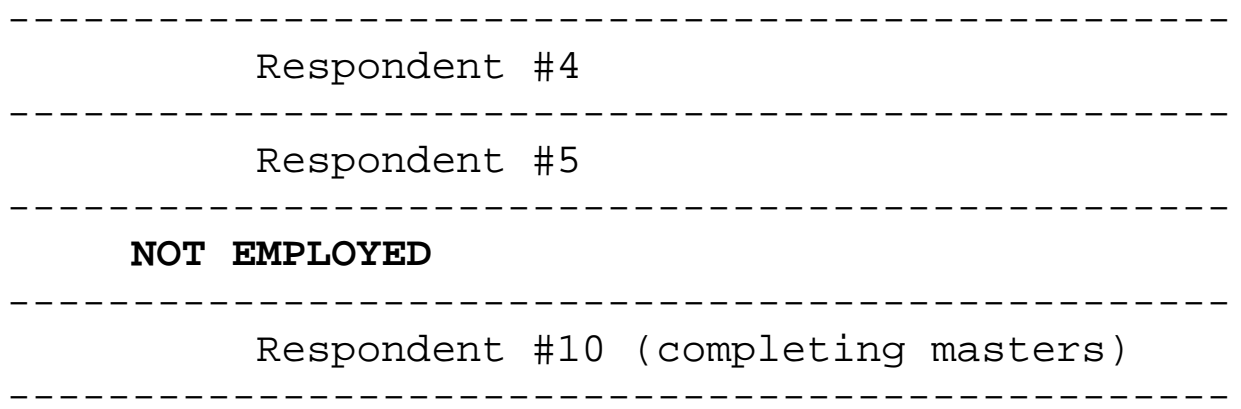

\section{Who is participating in yard sales?}

An overwhelming percentage of my respondents were female (80\%) as compared to only $20 \%$ male, which is typical of the informal economy. I expected that several, if not all of my respondent's would be female. The average age of the respondent's was 51, which was higher than I had expected. I thought that the average age would be in the late $30 \mathrm{~s}$ to early $40 \mathrm{~s}$.

I hypothesized that the number of males in 
my study would be low and only 2 males were participants in the study. The percentage of males would have been smaller had the other 4 females who had originally agreed to be interviewed completed an interview. One of the males, Respondent 5 was intensively involved in yard sales, having 2 a year at his residence, which is the maximum number allowed for people living within city limits, and $4-6$ at an alternate location, while Respondent 8, the only other male in the study only casually participated, having one yard sale per year on average. I thought it was helpful that the 2 males in the study had different levels of involvement so that they could adequately be compared with their female counterparts to examine if there were differences between males and females.

The 6 respondents who were marginally involved in yard sales all responded to the question "Do you consider your participation in yard sales to be a business activity, a hobby, or something else?" with the answer "something else." In one form or another, the casually involved respondents answered that their participation was to get rid of items that were no longer of use to them. Some of the reasons 
those casually involved give for having yard sales:

"I have two small children and they are constantly growing out of things, plus I accumulate so much junk in a given year. Having a yard sale is a good way to get rid of things and to make a little extra cash." (Respondent \#1)

"I hold yard sales mainly to get rid of things." (Respondent \#3)

"It's a good way to meet people and make a little money." (Respondent \# 5)

"I would say that almost totally the reason is to get rid of accumulated things. I don't really like to do it (have yard sales) much, but it's an easy way to get rid of things." (Respondent \#8)

Only one of the 4 respondents who were intensively involved in yard sales responded to the above questions with "business activity" . This respondent Ethel was a 75 year old retired professional, who also had the highest level of education in the study. The other 3 intensively involved respondents all responded that their involvement in yard sales was a hobby. These 3 respondents were Respondent 2, a housewife; Respondent 5, a retired plant worker, and Respondent 9, a housewife. Respondent 2 had only 2 yard sales per season, but she stated that 
"it's a good way for us (her family) to earn some extra money." Also, she has hosted yard sales for 10 years and kept the frequency at 2 per year, so it stands to reason that she does expect a certain amount of income from this activity. If she didn't feel this activity was profitable or worth her while, she would not continue with it. My observation was that she does not need the money, so much as she expects it.

Respondent 5, also claimed that yard sales were a hobby for him, but evidence points to his involvement as being more of a business venture than a hobby. He hosted the allowable 2 yard sales within city limits and $4-6$ at an alternate location. The other location was a lot that the owner charged $\$ 10$ on Saturdays for people who wanted to bring their wares to sell. Respondent 5 said the area was outside of Fayetteville near a grocery store, and in a good traffic location. The owner of the lot advertised in local newspapers, as well as the local trading papers. He said that the advertisement and word of mouth had made the spot popular among yard salers and usually had a steady flow of customers. Respondent 5 held 4-6 yard sales at this location and usually only held yard sales July through September, because he stated, "I have found these 
months to be the most profitable due to the weather and the flow of tourists through this area at this time." From his comments, I observed that this respondent is taking advantage of the cyclical nature of Fayetteville's tourism.

Respondent 5 seemed flattered to be interviewed, but on the day of the interview he seemed a little more hesitant. He wanted to look over the questions beforehand and told me that he had a problem with Question 5: "What is the average income you earn from yard sales in an average yard sale season? Is that amount a significant part of your household's income? Roughly, what percent? What do you use the money for?" He stated that he didn't feel comfortable with the question because "I've worked hard all of my life for my social security and this could interfere." I assured him that the interview was confidential, however he was adamant, so his interview was the only one not recorded. His reluctance to have the interview recorded and to report the income could indicate why he said that his yard sale activity was a hobby when it clearly seems to be a business activity.

Due to his refusal to answer questions about his yard sale income, I can only guess as to how important this activity is to him. I do not 
believe that he needs the sales to survive, however, I do believe that the sales are a supplement to his social security and possibly provide a safety net for him and his wife. Respondent 9, was the final participant who was intensively involved in yard sales. She is a 62 year old housewife who has been hosting yard sales for 12 years. She now holds around 5 a year, which is an increase from when she first began. She was positively reinforced by the amount of money she was making, therefore she increased her frequency of yard sales to one a month April through August. She states, "After I first started having yard sales about 12 years ago, I figured out it was a good way to make money, so I started having more per year." Though Respondent 9 only holds one sale per month during the warmer months, she is constantly preparing, gathering items and organizing them. This respondent lived about a mile outside of city limits, so she was exempt from the 2 yard sales per year ordinance.

Respondent 9 classified her involvement with yard sales as a hobby, however, it clearly appears to be a business activity. Also, more so than any other respondent, she needs the money she earns from yard sales. I observed that this 
respondent seemed to be the poorest respondent. Her house looked rundown on the outside, and it was quite small, though she kept the inside very neat. Both times I saw her, she had on clothes that looked very worn, and she and her husband only had an old truck for transportation. Also, she was the only respondent who mentioned that yard sales had helped her family get by before, and she was the only respondent who had items donated to her from someone outside of her family. When asked what percent of her household income came from yard sales, she replied: "I'm not sure, but the money has helped pull us through some tough spots, and it helps with things such as buying Christmas presents for our grandkids."

Her involvement indicates that she is involved in a business venture, rather than a hobby. The money she earns helps her family to get by. This year she indicates she would be able to use most of the money for Christmas presents for her grandkids (14), though she would have extra money "if something comes up." There could be various reasons for respondents to claim they were involved in hobbies rather than business activities. The respondents may think that they don't spend 
enough time doing it to consider it a business activity. One reason for this could be because they are not relying on the money to be a substantial portion of their household income, so they feel they are not making enough money to classify their involvement as a business activity

Another reason for dismissing their continued involvement as a business activity could be legal issues. Involvement in the informal economy can be risky because the vast majority of the people aren't reporting this income, which can cause worry among those participating. This was illustrated by Respondent \#5, who not only refused to be taped, but also refused to answer any questions regarding his income from yard sales.

A final reason may be that some of the characteristics of their activity could point to being a hobby. Of those intensively involved (Respondents 2, 4, 5, 9), only Respondent 2 did not mention "meeting people" as a reason for participating in yard sales. Comments from the other 3 include:

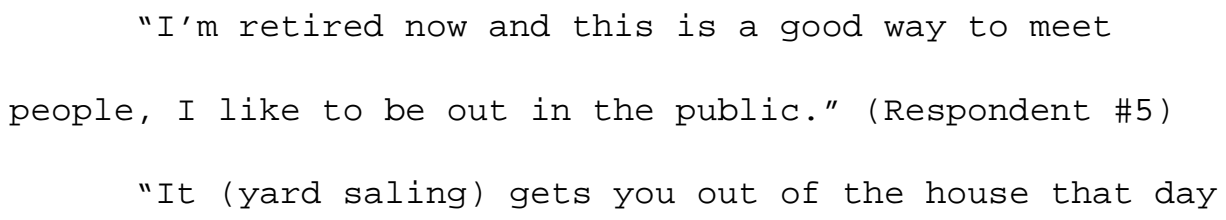


and hardly equals no cooking or housework. You enjoy the freedom of being outdoors on a beautiful day and we meet swell folks." (Respondent \#9)

"Another reason I like yard sales is because of all the nice people you meet. Well, I've met a lot of nice people from West Virginia. In Florida, when my husband was still alive, we had a few yard sales and people just weren't as nice as they are here." (Respondent \#4) Money is not the only reason these people participate, though it does seem to be the most important reason for participation among those that are intensively involved. The three respondents who named "meeting people" as a reason for hosting yard sales were the 3 oldest respondents in the study. This seems to indicate that this is part of their social life, as theirs may have diminished over the years. The respondent's other reasons for participation could be part of the reason, these respondents classify their involvement as a hobby, rather than a business activity.

\section{Respondent's Yard Sales}

Several questions were asked of the respondents about the yard sales that they hold. One particularly important question was what types of items the respondents were selling. This question is important because I wanted to find 
out what was selling best and what items the respondent's were making the most money on. There was a wide variety of answers, however there were some similarities among the respondents. Some of the answers given for items sold were antiques, what nots, household items, toys, clothes, furniture and tools. The two items that were most often sold by my sample were household items and clothing. When asked to elaborate on household items, some of the responses included sheets, towels, furnishing and kitchen items. The respondents that mentioned clothing most often sold children's clothing, though some also sold adult clothing. Overall, the respondents sold a wide variety of items.

The respondents were also asked which items sold best, which provided a multitude of answers as well. Many of the respondents gave more than one answer for this question, but the answer given the most often was children's clothing. As one respondent pointed out:

"Kids grow out of things so fast that the clothes are still like new when the child grows out of it, so kids clothes sell well. Another reason is that kids stuff is so expensive that a lot of people are looking for that at yard sales. My kids' old stuff always brings in the most money." (Respondent \#7) 
Household items were the second most named item regarding what sells best at yard sales. One respondent stated that it depended on the time of year when determining what sells best. He elaborates:

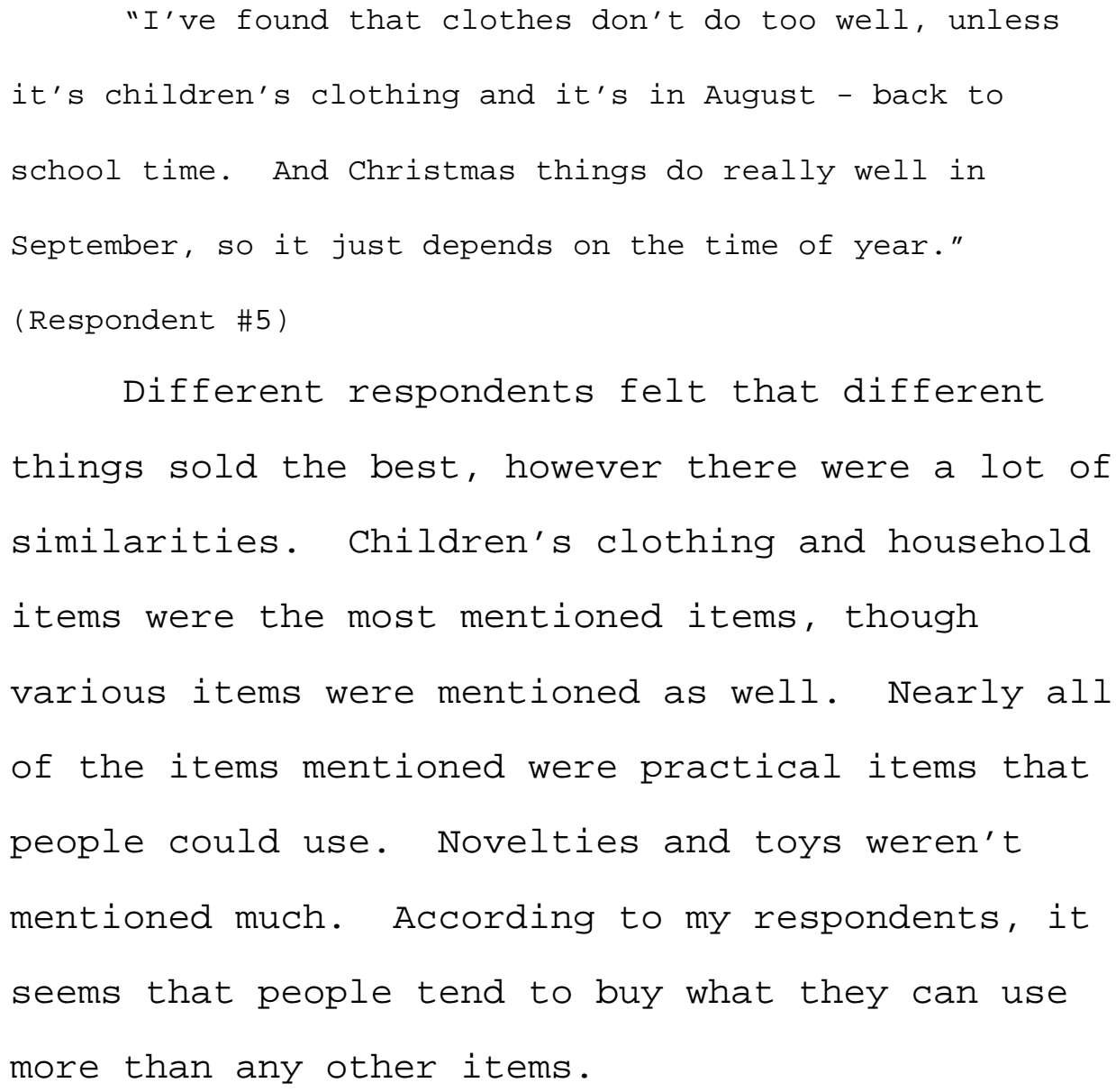

\section{How Respondents Prepare for Yard Sales (advertising and pricing)}

The respondents had various methods of preparing for yard sales. Several respondents had specific methods on how to organize their items beforehand and set them up on the day of the yard sale. Questions were asked of the 
respondents on how they prepared in general, and the respondents were asked specifically about their methods of advertising and pricing. The respondents answers had many similarities concerning their methods of advertising, while the methods the respondents used to price items had more variation.

The respondents were asked if they advertised their yard sales by formal or informal methods and but one respondent claimed to use one or both methods. (See Table 3).

TABLE 3

METHODS OF ADVERTISING N

INFORMAL
FORMAL
INFORMAL AND FORMAL
NO ADVERTISING

Ninety percent of the respondents used some type of advertising, while 70\% used formal and informal advertising. All of the respondents who utilized formal methods used informal methods as well. One respondent (\#5) didn't use any method of advertising. He explains:

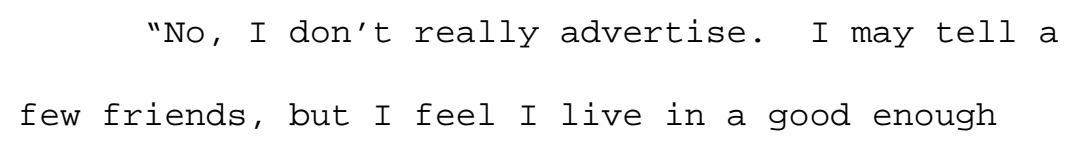




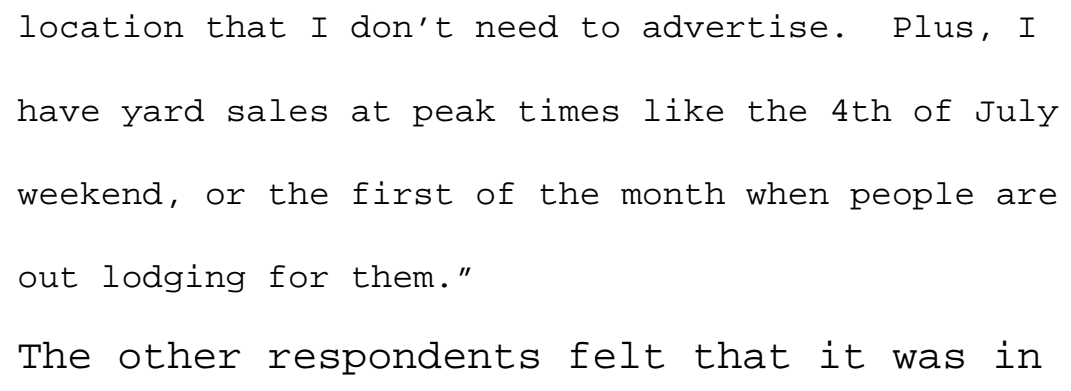


make, so they put forth time and effort to make it successful.

The techniques used to price items varied among the respondents, though there were some common themes. Most of the respondents provide everything or most everything, though there were a few exceptions (See Table 4). All of the respondents had some form of organization, though some methods were more elaborate than others. For example, Respondent 6 stored her things in an outside building and began preparing for the yard sale one month prior to when it was scheduled. She explains:

A month ahead of time I like to go up (to the storage building) and start sorting them out into, you know certain items into certain places. I put all the clothes off to one side and I try to separate the winter and summer things and then I just start pricing. If something has a spot, I wash it and if it has a rip I sew it. I want the things to be nice." Though the above respondent (\#6) has only 1 yard sale per year, she prepares as if it's a business activity, though she is only a casual

participant. Other respondents are quite as meticulous when it comes to preparing the items and pricing them. For example, when I attended Respondent 1's yard sale, the things weren't 
organized in any manner that I could pick out, other than the clothes being put in the same place. When I asked her about her method of preparing and pricing, she replied:

"This year we didn't price anything because we

didn't have time, but usually we put the sticker tags on

them." (Respondent \#1)

Some other comments on pricing:

"I just put everything on a table as one price." (Respondent \#2)

"I generally try to determine how badly I want to get rid of something and whether or not it's going to be something that if I don't get rid of, I want to keep. If I want to get rid of it real badly, I price it low, and then I try to determine what people expect to pay at a yard sale." (Respondent \#3)

"I try to price everything, I think that's best. Some people pick up something with no price on it they probably think maybe it's in excess of what they would want to pay for it." (Respondent \#8)

Two of the respondents in this study did not price their items and their reasons were nearly identical as to why they chose not to price. Both of the respondents who chose not to price did so because they preferred to price as Respondent 5 put it "according to clientele." These two respondents, who were intensively 
involved in yard sales chose to use verbal pricing based upon the appearance of their customers. They did seem to have an idea of what they wanted for their items, but they chose not to put prices on them. When asked about pricing Respondent 4 replied:

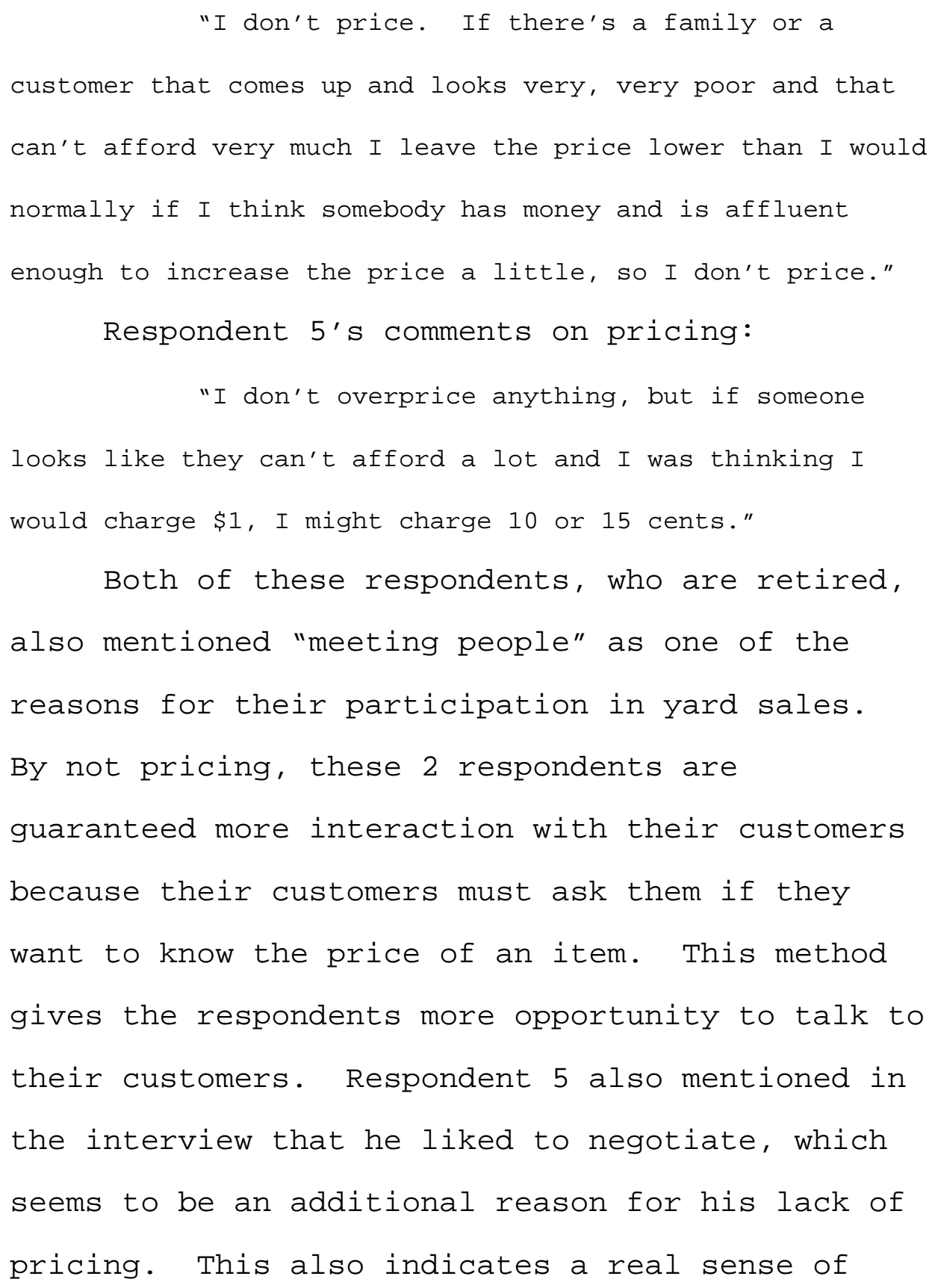


community, as these respondents have a willingness to help out local people who do not have much.

\section{Sources intensively involved use to obtain}

\section{items}

$$
\text { Questions were asked of the intensively }
$$
involved regarding how they acquired their wares. I hypothesized that if someone has more than 1 yard sale per year for several consecutive years, they will have to receive items from various sources. As I expected, all of those intensively involved had sources to obtain things to sell, other than their own possessions. Oberhauser points out in one of her studies that participants in the informal economy often have to have networks of people from which they may receive materials from and others who function as customers (1995). Due to her findings, I expected that my respondents would also have to have sources to obtain items to sale, because I felt that 1 person or family would not have enough excess to continually participate in yard sales.

All four of the respondents who have multiple yard sales yearly received items from people that they knew and 2 of those respondents also went to other yard sales to buy things with 
the specific intent to resale them, indicating business activity. Respondent 2, a housewife who had 2 multiple day yard sales yearly stated that her son gave her grandchildren's things that they had grown out of to sale. This helped her to have things to sale. She didn't mention any other sources of obtaining items and she said that she did not buy items at other yard sales to resale.

Respondent 4, a retired schoolteacher who averages about 3 multiple day yard sales per year, had various sources from which she received items to sale at her late mother's things, some of her sister's things, her son's, her grandson's and some of her niece's unwanted things as well. She said that these families gave the items to her because they knew of her yard sale involvement and they told her to get what she could for the items. Respondent 4 also classified her yard sale participation as a business activity, and having times from various sources helps her in her venture. She doesn't go to other yard sales, so the items she receives from several family members helps her to have a certain amount to sell at pure profit. Respondent 5 is also retired, and has 6-8 yard sales receives castoff items from family 
members as well. His son and his grandchildren give him their excess items to sell. Respondent 5 also utilizes other yard sales by purchasing items with the intention of reselling them.

Respondent 9, a housewife, is the only intensively involved respondent who doesn't receive things from her family. She receives items from a friend who gives her whatever is left over from her own yard sale, and friends of friends have also donated boxes of things to her. Respondent 9 also attends other yard sales looking for things that she believes that she can resell at a profit.

\section{Why do participants go to other yard}

sales?

I was also interested in asking if the respondents attended other yard sales. As I had expected due to previous research, I thought the respondents who were intensively involved would have to have various sources from which to obtain items, so I was interested in knowing if they obtained items from other yard sales to resale. I was also interested in finding out if respondents used yard sales to buy things they need. Though they may not be intensively involved, they may go to other yard sales to buy things that they need, which would qualify as 
indirect involvement in yard sales. If they did, I inquired about their reasons for doing so. Eighty percent of my respondents (\#1, \#2, \#3, \#5, \#6, \#7, \#8, \#9) did attend yard sales for various reasons. Seventy percent (\#1, \#2, \#3, \#6, \#7, \#8, \#9) attended to buy things that they could use or needed, though some attended yard sales frequently, while some only stopped occasionally and didn't actively seek them out. The respondents (\#5, \#9) attended yard sales to buy things that they planned to resale at their own yard sale, while Respondent 9 also bought things that she needed.

Though the majority of my respondents went to other yard sales, they had varying frequencies. Some of the respondents stopped often at other yard sales. Some of their comments :

"I go to other yard sales, but I just buy things I need." (Respondent 7

"I go to yard sales for different reasons. I look for things I can use or need to save money and sometimes I buy things to resale."

"I go a lot to other yard sales. If we find items reasonably priced that we can use, we buy them. It saves a little money." (Respondent 2)

Comments from those respondents who attend 
only occasionally:

"I don't go as much as I used to, but when I am going, I look at the house. If the house is junky looking, junkier than mine, you know, like the outside. If the house looks worse than mine, I don't go. I want something nice, I don't want to buy garbage." (Respondent 6)

"I occasionally go to other yard sales, not frequently. If I see one, I may stop but I don't look them up or seek them out." (Respondent 8)

Comments from respondents who don't attend yard sales:

"No, not here. I did (go to yard sales) in Florida, but I haven't been to any here, not even one. As a matter of fact, I've got so much of my own I'm going to shoot myself if I go to another yard sale." (Respondent 4)

"For one, I don't really have the time. I work in the summers Monday through Friday, so on the weekends I do other things, so going to a yard sale never really crosses my mind." (Respondent 10)

Two of this study's respondents frequented other yard sales to purchase what they believed to be underpriced items that they would try to sell at their own yard sales. Respondents 5 and 9 were the respondents who utilized other yard sales. They were both intensively involved in the activity, and coincidentally, these 2 participants hosted more yard sales than any of 
the other subjects in the study.

Both admitted to going to other yard sales to purchase items to resale, however, the two had very different methods of doing so. Respondent 5 went to other yard sales only to buy things he would sell again. He said that he bought a variety of items and that "it just depends on what is underpriced." This respondent did not participate in buyouts, where he would approach someone at the end of the day and offer to buy all of their things at a flat rate. He felt that he had even involved in yard sales long enough to know what prices items went for, so if he saw an item that he thought would sell well and was underpriced, he would buy it. Respondent 5 especially did this with tools. Some of the items he buys, such as a weedeater might only need a small, inexpensive part to run again. He knows if he buys this item, he can fix it himself and sell it for much more because it is now fixed. Though Respondent 5 does buy a multitude of items, he focuses on buying tools. He elaborates on his activity:

"Yes, I do go to them (other yard sales) to buy things I plan to resell at my own. I buy a variety of things, but mostly tools. I have lots of tool parts here that I've bought and just have, so I'll buy tools at other 
sales to fix up and store until my next yard sale. I mark 'em up at least $20 \%$ of what I originally paid."

Respondent 9, a housewife, is the other respondent who buys at other yard sales to sell at her own, however, she also buys things she needs to save money. Respondent 9 told me that she first looks for things that she needs or can use, and then she also looks around for things she can sell. She confides:

"I don't look for particular items to sell, but when I do buy stuff to sell again, I buy things like dishes, what nots and toys. I don't mark them up a certain amount, just whatever I think I can get for an item. You might make only a quarter or 50 cents on some things, but every little bit helps."

Respondent 9 is the only participant who uses yard sales for monetary gain, as well as a way to save money. She did seem to be in need of this money moreso than the other participants, which could explain her different levels of involvement.

Although all of the respondents were asked if they thought of other yard sales as competition, I hypothesized that any feeling of competition would come from those with intensive involvement. Actually, all of the interviewees responded negatively when asked if they viewed 
other yard sales as competition. The respondents who were only casually involved often laughed when I asked that question. The intensively involved did not laugh at the question, but also responded that they did not view other yard sales as any kind of threat or competition. Their responses to the question (Do you consider other yard sales to be competition? Why or why not?):

"No. Everybody's just trying to get rid of things and make a little money." (Respondent 2)

"No, not really. I don't begrudge anyone trying to earn extra money." (Respondent 4)

"No, I don't see them as competition. It's only a hobby of mine." (Respondent 5)

"No, not really. Everybody's trying to make money." (Respondent 9)

Interestingly, even though Respondent 9 said she felt other sales weren't competition, when asked when the best month to hold yard sales was she responded April or May. Her reasoning was that at that time it's early in the season and there aren't as many yard sales around. This seems to convey that she and other respondents may be more concerned with money than they are willing to admit, so they answer that there is no feeling of competition, though for some respondents a level of competition may exist. 
She may feel some level of competition from other yard sales, but be unwilling to admit it.

\section{General Knowledge of Yard Sales}

The interview included queries on the

respondent's knowledge of general aspects of yard

sales, such as what make a certain yard sale

desirable, and what steps someone interested in

having multiple yard sales in an attempt to make

a significant amount of money would have to do to achieve this.

When asked what made a certain yard sale desirable, the respondents provided a host of answers. (See Table 5)

* When a specific item was mentioned, it was counted separately from when someone replied

"appealing items."

* * Some respondents gave more than 1 answer. 
TABLE 5

WHAT MAKES A YARD SALE DESIRABLE

\begin{tabular}{|c|c|}
\hline & $\mathrm{N}$ \\
\hline APPEALING ITEMS & 4 \\
\hline GLASSWARE & 1 \\
\hline CLOTHING & 1 \\
\hline HOUSEHOLD ITEMS & 1 \\
\hline FURNITURE & 3 \\
\hline ANTIQUES & 2 \\
\hline AFFORDABLE ITEMS & 1 \\
\hline WELL KEPT HOUSE & 5 \\
\hline ADEQUATE PARKING & 1 \\
\hline $\begin{array}{l}\text { CONGENIAL HOST } \\
\text { CO--1 }\end{array}$ & 1 \\
\hline
\end{tabular}

I was somewhat surprised that several respondents (50\%) put so much stock in the looks of the house. Those respondents that mentioned a well maintained home was the key to finding a yard sale seemed to agree that typically a nice house would have nice things to sell. Respondent 4 says:

"People who live in a nice house and are affluent will have nicer things. This is a general rule, 
so it has exceptions."

Most of the other answers included certain items that the respondent answering found desirable, which

was expected. The participants in this study will stop at yard sales with items that appeal to them, as most (70\%) of the respondents mentioned items in general, or specifically named items as at least one of the reasons a sale would be appealing. Of the 3 that didn't, they all mentioned that if the house is nice the things will be as well. If someone has a nice house people may assume the things are nice, because this is how they may look at a business. If the items appeal to them and the place of business looks appealing, they will shop there, and this may be the gauge they use for yard sales as well.

The participants of this study provided numerous answers concerning what someone must do to be successful at using yard sales to make a significant amount of money. Some of their suggestions:

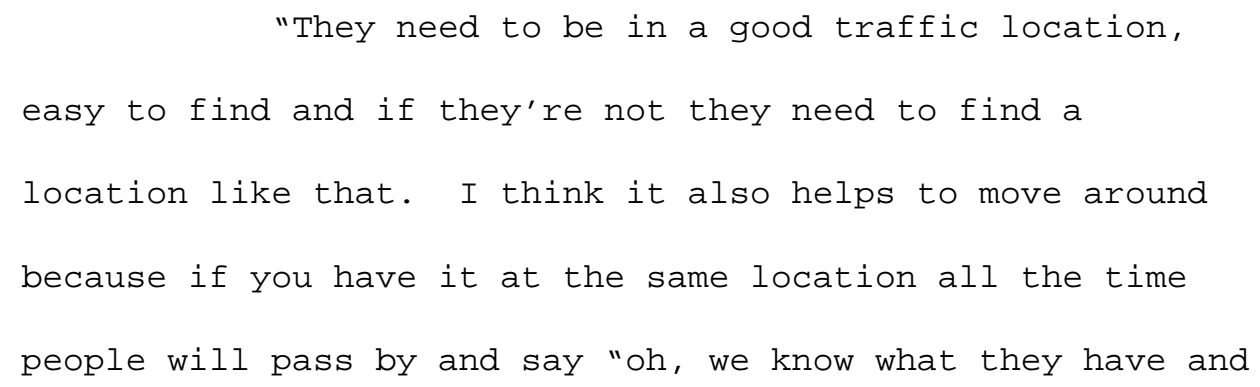


move on." (Respondent 3)

"The people need to be congenial and sociable, have a knowledge of what people want, and be able to adjust to the flow of business." (Respondent 5)

"They probably need to go to other sales and buy things to resale. You could start by cleaning out your own house." (Respondent 6)

"First of all, you have to price realistically, because you can't get big money at a yard sale on a given item, and you've got to advertise I feel. If you live in a real busy neighborhood, traffic-wise then probably just the signs in the yard would be fine. You also have to have different merchandise, because people see things 2 or 3 times they won't come back. You have to change or add to your merchandise. You'd have to buy items at such a reduction that you could sell them and make a little money off them. I know of some people who buy out people at the end of the day." (Respondent 8)

"Well, you need to make sure everything is nice and clean and organized. You also have to go to other yard sales and buy things. People give me stuff, too, so I have that source too." (Respondent 9)

"They would have to buy from or buy out other yard sales. They also need to keep in touch with what sells and what people want."

These quotes illustrate that anyone who wants to use this as a business venture must have 
other sources to receive items to sell, which would require financial and social capital. You must have a network of people who can provide you with things to sell or if you go to other yard sales to buy some or all of the items, negotiating skills are required, which constitutes as social capital as well. Also, several respondents mentioned other things may require social capital such as knowing the items that people want to buy, being social, advertising, living at or finding a good location, and having everything organized and well kept.

According to my respondents, it seems that anyone who wanted to have repeated yard sales would have to have enough savvy to know what people look for and at what price, be congenial, be able to negotiate, advertise, and hold the yard sale in a good traffic location. This requires financial and social capital, which people of the poorest socioeconomic classes may not have (cite). Also, transportation would be required to travel to other yard sales to obtain items to sale. Also, it seems that often people may look at someone's house as an indicator of the types of merchandise the person will have. This puts people of lower social classes at a 
disadvantage. For example, Respondent 3 who lived in the largest house of the people I interviewed, seemed to be fairly affluent and said she usually makes $\$ 500$ - \$600 in a 2-3 day yard sale, and only holds one per year. On the other hand, Respondent 9, the most disadvantaged participant might make $\$ 700$ in a whole season of yard sales. She holds 5 per year, and sometimes these are multiple days. Also, she relies on other people for a portion of her merchandise, while Respondent 3 only uses unwanted or unneeded items from her household. Without a network of people donating to her, Respondent \#9 would likely not even make significantly less than the $\$ 700$ she averages. 


\section{CHAPTER 5}

\section{Discussion and Conclusion}

The research questions I wanted answered when I began this research were who participates in yard sales, how extensively do they participate and what are their reasons for participation. I expected that the majority of my respondent's would only participate occasionally as a way to get rid of things they didn't want and to make some extra money. I hypothesized that the people that did participate more extensively were of lower socioeconomic classes than their counterparts who participated only occasionally, and they did so because they needed the money more.

The majority of my respondents (60\%) did participate only occasionally and of the remaining 4 who were more intensively involved only 2 of those had 5 or more yard sales per season. Two of the intensively involved respondents were of lower social classes and both were housewives and had never worked formally. These 2 respondents could be considered members of lower social classes, but were not members of the lowest social classes, such as the "working poor." The other 2 intensively involved respondents were both retired workers. They were 
not of low social classes, however, due to retirement their income was significantly less than what it had been while working, so they also need a supplement to their income, not for survival, but to help maintain their middle class standard of living.

The 4 intensively involved participants were older as well. The youngest of these respondents is 60, and the oldest is 75, and coincidentally, these were the oldest 4 respondents. This was somewhat unexpected. I expected that the more intensively involved respondents would be younger and still have children at home.

I argued that there would not be a high number of men, due to other study's findings that women mostly participate in the informal economy. This is what I found within my study, with only 2 men out of 10 respondents. In addition, the 4 who agreed to interviews and later refused were all women, so had they been part of the study the percentage of men would have been even lower. The education level was slightly higher than expected, though more respondents were high school graduates (4) than any other category, which was anticipated. I did think there would be more high school graduates and less college graduates (3 bachelors, 1 masters). There were 
also 2 respondents who did not finish high school, and both of these respondents were housewives who were intensively involved in yard sales. It was also expected that those intensively involved would have less education than their counterparts, and for the most part occurred with 2 who did not finish high school, on high school graduate, and 1 masters degree. I was somewhat surprised to have a respondent intensively involved who had a masters, however, she was retired and had only being involved intensively upon retirement.

The reasons for participation varied and some were the reasons I argued the respondents would most likely give. Actually, I only received 3 responses when asked for reasons of participation. All of the respondents gave one or a combination of the following on why they participated (no distinguishing order): to get rid of accumulated things, to make money, and to meet people. I didn't not expect that meeting people would be considered by my respondents as a viable reason for having a yard sale, but 3 felt that it was. Those 3 were older (2 retired, 1 housewife), and all intensively involved. This was a way for the retired people to meet and talk to people as they had while working, and for the 
housewife in her words, "a way to get out of the house."

Though my 3 main areas of concern were to examine who participated, how extensively, and why, I also wanted to analyze what my respondents could tell me about yard sales in general, so I could achieve a better understanding of yard sales and their place in the informal economy. For instance, I learned that though my respondents weren't making large amount of money per yard sale, repeated ones could accrue an amount of money that would be valuable to a household. Respondent 9 had at times made $\$ 800$ \$1000 in a season, which was probably between 3\%6\% of her household's total income, which can make a significant difference, particularly if it's tax free. The respondent (3) who made the most money for one yard sale $(\$ 500-\$ 600)$ didn't need the money to get by. She was merely trying to get rid of unwanted things.

I also learned of the various methods of advertising and pricing that respondent's used. The vast majority (90\%) employ either formal or informal methods of advertising and 70\% use both. The typical forms were hanging signs within the yard or at the beginning of the road in which the respondent lived on (informal), or putting an ad 
in the local trading papers or the local paper (formal). In this study, if someone employed a formal method they were more likely to use an informal method as well, while respondents who used informal methods weren't quite as likely to use formal methods.

Concerning pricing, 80\% priced at some level, 2 did not price at all and 1 used a mix of verbal and written pricing. The three who used at least some verbal pricing were all intensively involved and the 2 who did not price at all chose to do so because they wanted to see the clientele first. These 2 yard salers adjusted their prices according to how their potential customers looked. This was a very interesting finding and one I did not intend to find. The majority of the respondents felt it was better to price so that it was easier to remain firm and limited confusion.

I hypothesized that those who were intensively involved would have to have other sources that they could obtain items to sale from. This was proved with all 4 intensively involved respondents having other sources who gave them things, or went to other yard sales to obtain items. Two of the respondents obtained wares from their families only, one received from 
his family and shopped at other yard sales to buy and resale, and one respondent was donated items from friends and acquaintances, as well as using other yard sales to obtain merchandise. $80 \%$ of the respondents attended other yard sales and of those, 7 went to buy things that they could use or needed. Two went to obtain merchandise, one of those also one who used yard sales to get things she needed "to save money." Of the two that didn't go to other yard sale, 1 claimed lack of time, and the other stated that she had too much stuff of her own to go to another yard sale and buy items.

I anticipated that respondents would answer that the items at the yard sale were important indicators of a desirable yard sale, and to a lesser extent I hypothesized that they may feel that items being organized and having a large number of items would also be reasons to stop at a yard sale. The respondents did think that the items were very important, however, immediately following that, $50 \%$ of the respondents stated that the look and condition of the house was a primary indicator of what the items would be like. Other things mentioned involved the sociability of the host, the location and if the parking was sufficient. 
The participants had several suggestions of what someone should do if they wanted to have yard sales repeatedly as a business activity to make a significant amount of money. The respondents of this study felt that to do that one would have to have a significant amount and variety of merchandise wherever they obtained it, be able to add to or change their merchandise, be in a good location, advertise and know what people want and would be willing to pay. Some of these suggestions require some business savvy, as well as social capital, which could put people of lower socioeconomic classes at a disadvantage. This may be why people of the lowest social classes were not in my study, as they may not have the resources to participate.

Yard sales are not the main informal economic activity in Fayetteville, which begs the question, what is? Yard sales are a part of the picture, but this research shows that there are obviously other activities that people use to supplement incomes. The respondents of this study were of a higher social class than expected and did not need the money as much as other families may. More research needs to be conducted to explore what activities families that must supplement their income take part in. 


\section{Iimitations}

There were several limitations within this study. First, there were only 10 respondents and they were all from one small town in West Virginia, which makes generalizations about yard sales everywhere impossible. Generalizations can be made about this particular population, however, it would be erroneous to try and make generalizations about yard sales based solely upon this study .

Fayetteville, West Virginia is a small and rural town much like the majority of West Virginia, however, Fayetteville is not as depressed as some regions of West Virginia and is above average in per capita income for West Virginia, and lower in unemployment. This could by a reason for the slightly higher education levels and why more respondents were not in lower socioeconomic classes.

Qualitative studies are valuable, however, they also take away some ability to generalize due to their size and having less questions than a quantitative study would typically have. This study was centered on certain topics, which could have hindered other topics from being broached. Respondents were permitted to elaborate, however they usually stayed within the parameters of the 
topic at hand.

Another limitation was the lack of funding. Without funding, this study had to remain on a small scale. Another limitation was the researcher. This was the first time I had taken on something of this magnitude, and due to this lack of experience I may not have picked upon certain things, or let the respondent take control of the interview more. Also, 4 people eventually refused to be interviewed and this could have been due to my lack of experience. Having completed this and listening to the interviews over and over, I can detect places where I should have probed more, and places where I should have let the respondent elaborate more before moving on. This is something will get better with experience, but the lack of experience was a limitation for this study.

\section{FUTURE RESEARCH AND CONCLUDING REMARKS}

This study scratches the surface of how yard sales work, what people use them for and their place in the informal economy. Much more research needs to be done on this subject. Now that a qualitative approach has been used, it would be helpful to use a quantitative approach on a much larger scale so that generalizations could be made. Some of the questions for this 
study could be transformed into close-ended questions. Also, due to some responses and finding within this study, an idea of what kinds of close-ended questions to ask has made it easier to know what types of questions to ask. I would like to continue this research on a much larger scale, using all of West Virginia. An approach could be going to yard sales and handing out a questionnaire for the host to fill out. This is a possibility and others are being considered as well.

This study was on a small scale, however, I feel it still has importance for understanding yard sales and their participants, as well as adding to the growing body of research on the informal economy. A profile needs to be made of the average yard sale participant and compared to the average participant of the informal economy. This will give us a better understanding of both when those generalizations can be made. 


\section{REFERENCES}

Castells, Manuel and Alejandro Portes. (1989). "World Underneath: the origins, dynamics, and effects of the informal economy." (pp. 11-37). in The informal economy: Studies in Advanced and Less Developed Countries, edited by A. Portes, M. Castells, and L. Benton. Baltimore, MD: John Hopkins University Press.

Jensen, Leif, Gretchen Cornwell, Jill Findeis. (1995). "Informal Work in Nonmetropolitan Pennsylvania". (pp. 91-107). in Rural Sociology 60(1). University of Illinois, Urbana-Champaign, Illinois.

Mencken, Carson F. and Sally Ward Maggard. (1998). "Informal Economic Activity in West Virginia: A Descriptive and Multivariate Analysis." Research Paper 9616, West Virginia University Regional Research Institute.

Oberhauser, Ann M. (1993). "Industrial Restructuring and Women's Homework in Appalachia: Lessons from West Virginia". in Southeastern Geographer 33,1:23-43.

Oberhauser, Ann M. (1995). "Gender and Household Economic Strategies in Rural Appalachia". Gender, Place and Culture 2,1:51-70. West Virginia University Regional Research Institute.

Oberhauser, Ann M. (1995). "Towards a Gendered Regional Geography: Women and Work in Rural Appalachia". in Growth and Change 26,2:217244. West Virginia University Regional Research Institute.

Tickamyer, Ann R. and Teresa A. Wood. (1998). "Identifying Participation in the Informal Economy Using Survey Research Methods" in Rural Sociology 63(2), pp. 323-339. University of Illinois, Urbana-Champaign, Illinois 
U.S. Bureau of the Census. (1990).

Characteristics of the Population. Washington, D.C.: Government Printing Office 


\section{APPENDIX 1}

\section{Incomplete Interviews}

Every person I asked for an interview agreed, however, there were 4 people that initially agreed to interviews that were never completed. In the first instance, the house I approached was in a middle class, residential neighborhood. The potential respondent's home was a large, 2 story house with a 2 car garage that was well-kept. The woman had 3 children playing in the yard and was reading a book when I approached. I was the only one at the yard sale at that time. The yard sale had 4 large tables of neatly arranged items. Some larger items, such as toys and appliances were arranged on the pavement of the driveway. The woman, who appeared to be in her early to mid 30s, immediately began chatting with me. As I purchased a few small items, I explained my study and asked for an interview. She immediately agreed with no probing and an interview was set up for 2 days later. When I arrived at her house, the lady came to the door and explained that she had forgotten about the interview and that one of her children had had some dental work done and was not feeling well. She asked if we could reschedule, which I agreed to, so we 
planned the interview for the next day. I again wrote the date and time for her. The next day, however no one was home. I left a note on the door stating that I must have missed her and I rescheduled the interview and left a number that she could contact me at if the time was inconvenient for her. I never received a call from her, so I again went to her house and no one was home. I decided not to contact her again, as she had obviously changed her mind about the interview for some reason and that she did not wish to participate in my study.

The 2 nd and 3 rd time I was avoided for an interview were connected. When I was driving through a designated area looking for a yard sale I saw and followed a sign for a yard sale, which actually turned out to be a joint venture. The road was a gravel road and very uneven and there were only 4 houses located on this road. The yard sales were located in 2 yards, which were side by side. The sign had only been for a "yard sale" and the two women were sitting together in one yard. As I approached, one woman got up and went to her own yard. As I approached, one woman got up and went to her own yard. As I chatted with the women I learned that they were motherin-law and daughter-in-law. The mother-in-law's 
house was a one story house of medium size and the house itself was in good condition, though the porch and yard were cluttered with things that were not part of the yard sale. The sale items were plentiful and there were many desirable items, such as household items and some furniture. The daughter-in-law lived in a trailer that was small and not well-kept, nor was the yard in good condition. The items at the yard sale were mostly odds and ends and did not contain many items that were desirable at a yard sale, such as appliance, decorative items, or children's toys and clothing. In addition, there were only 2 tables of items. Also, some of these items had a must odor and were dirty and dingy. After I had chatted with the older woman for awhile, I asked her for an interview and she agreed. Actually, The seemed flattered that I wanted to interview her. She said to me, "I'd be happy to talk to you, but I don't know if I would be of any help." I assured her that any information she could provide me would be fine. She said okay and we set up an interview for the very next day. Immediately, I went to the daughter-in-law's sale and purchased an item and asked for an interview. She agreed and I explained that her mother-in-law was also doing 
an interview and if she would like I could interview her immediately following her motherin-law's interview, which was scheduled for the next day. She said that would be fine because she had no car of her own and relied on rides from her mother-in-law, so if her mother-in-law was available she was as well.

When I arrived to interview the 2 women, there was a note on the mother-in-law's fence. The note said that they had forgotten that they had some appointments to go to and they were sorry for inconveniencing me. On the back of the original note I rescheduled the interview for the next day at the same time. I left a number I could be reached at, so that they could call and reschedule if the time was inconvenient for them. That evening the daughter-in-law left a message for me saying that she would be busy all week with "appointments" and that she would get in touch with me when she was available. I decided to call and try to schedule an interview one more item. I reached her husband and explained what I was calling for. He didn't seem to understand and said he would give her a message to call me. However, as I expected, she never returned my call.

The final instance of a potential responded 
avoiding a scheduled interview was with a woman who looked to be in her mid to late forties. As I was driving through a designated area, I spotted signs that led me to this lady's house. She was sitting in a lawnchair reading when I approached. Upon seeing me she ceased reading and struck up a conversation with me. We talked as I browsed, and every time I would pick up an item to look at the price, she told me that she would lower the price to " $x$ " amount. As I was purchasing my items, I explained my study and requested her participation. She seemed hesitant about an interview, so I again ensured her that any information she could provide would be very helpful and that all of her answers would remain confidential. She did not work, but she said she often was busy during the week and asked if the interview could be conducted by phone. I said that would be fine and we worked out a 2 hour time frame that was acceptable Monday through Friday for me to call. I tried to reach this woman 3 times during the allotted time and each time I was told she was unavailable. 


\title{
Appendix 2
}

\section{Interview Schedule}

\author{
Basic Personal Information
}

\author{
-Gender \\ -Age \\ -Ethnicity \\ -Grid Location of Fayetteville \\ -Highest level of Education Achieved \\ -Social Class Classification
}

\section{In-Depth Questions}

1.) How often do you participate in yard sales in an average year? During what months of the year do you hold yard sales?

2.) What are the reasons you participate in yard sales? Do you consider your participation in yard sales to be a business activity, a hobby or something else?

3.) What is the average income you earn from yard sales in an average yard sales season? Is that amount a significant part of your household's income? Roughly, what percent? What do you use the money for?

4.) Do you participate in any other economic activities after yard sale season is over? If so, what do you participate in during other times of the year?

5.) When did you begin hosting yard sales? Has the frequency increased since you began? If so, why?

6.) What types of items do you sale? What sells best? Who are your customers? Are they repeat customers? Are they mostly local? 
7.) Do you advertise your yard sales either formally or informally? Which methods do you use?

8.) Explain the process that you go through to get ready for a yard sale, such as advertising and pricing.

9.) Is there a specific time of the month or week that is better than other times of the month or week in respect to having a successful yard sale?

10.) Is there a particular month that you have observed as being better for having yard sales than any other month?

11.) Do you go to other yard sales? If so, do you go to other yard sales with the specific intent to buy items that you will then resale at your own yard sales?

12.) If you buy things at yard sales to resale at your yard sale, do you have any method of changing the price, say by marking it up 15\% or $25 \%$ ?

13.) Do you consider other yard sales to be competition? Why or why not?

14.) Are there any people that are known to have yard sales with desirable things that people are particularly interested in attending?

15.) What makes certain yard sales desirable, while others would be considered inferior?

16.) What is important to know if someone wanted to begin having repeated yard sales in an attempt to make a significant amount of money? 